Edu Consilium: Jurnal BK Pendidikan Islam Vol. 2, No. 2, 2021, hlm. 53 - 61

DOI: $10.1905 /$ ec.v1i1.1808

ISSN 2503-3417 (online)

ISSN 2548-4311 (cetak)

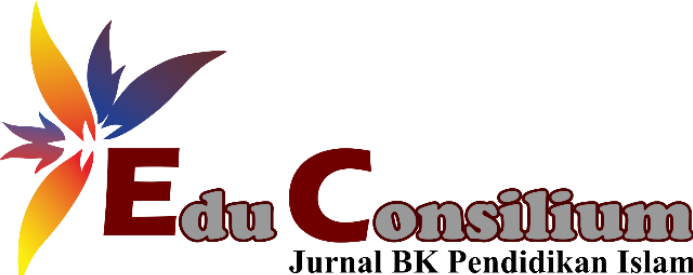

Jurnal BK Pendidikan Islam

\title{
PERSEPSI SISWA MA ATTARAQQIE KOTA MALANG TERHADAP PEMBELAJARAN ONLINE SELAMA MASA PANDEMI COVID-19
}

\author{
Fayrus Abadi Slamet", \\ ${ }^{1}$ Bimbingan dan Konseling Islam, Fakultas Dakwah dan Komunikasi Islam, IAI Sunan Kalijaga Malang, Jalan \\ Keramat, Desa, Dusun Gandon Barat, Sukolilo, Jabung, Malang, Jawa Timur 65155 \\ e-mail: fayrusslamet@gmail.com.
}

\begin{tabular}{|c|c|}
\hline & Abstract \\
\hline $\begin{array}{l}\text { Keywords: } \\
\text { Keyword 1; Online } \\
\text { Learning } \\
\text { Keyword 2; Perception } \\
\text { Keyword } 3 \text {. Students }\end{array}$ & $\begin{array}{l}\text { Online learning, which has been running for more than } 1 \text { year, creates various } \\
\text { perceptions or responses from students, so online learning needs to be evaluated. } \\
\text { Researchers consider it necessary to examine the perceptions of MA Attaraqqie } \\
\text { students regarding learning during the Covid-19 pandemic. This research is a } \\
\text { quantitative descriptive study using a survey, Data technique was carried out by } \\
\text { distributing questionnaires through Google Form media, online to all students of } \\
\text { Madrasah Aliyah Attaraqqie Malang City. This research to perceptions students of } \\
\text { online learning that has been carried out so far, so that it expected to be an answer } \\
\text { for students and provide solutions to the implementation of online learning at MA } \\
\text { Attaraqqie. The subjects of this study were all male and female students of MA } \\
\text { Attaraqqie Malang City in. This research using the Likert scale. The data was } \\
\text { obtained by filling in the questions using a Likert scale with the available answers. } \\
\text { The distribution of the questionnaire through the google form contained } 101 \text { student } \\
\text { respondents who were recorded. Based on the exposure of the research results, it can } \\
\text { he concluded that the students }\end{array}$ \\
\hline
\end{tabular}

Kata Kunci:
Kata kunci 1; Pelajaran Online
Kata kunci 2; Persepsi

Kata kunci 3. Siswa

\section{Abstrak:}

Pembelajaran online yang berjalan selama 1 tahun lebih, membuat persepsi ataupun tanggapan dari siswa bermacam-macam, sehingga, pembelajaran online perlu di evaluasi. Peneliti menganggap perlunya untuk meneliti persepsi siswa MA Attaraqqie mengenai pembelajaran selama masa pandemi Covid-19. Penelitian ini merupakan penelitian deskriptif kuantitatif dengan menggunnakan metode survey, teknik pengumpulan data yang dilakukan dengan cara menyebarkan angket melalui media google form, secara online kepada seluruh siswa Madrasah Aliyah Attaraqqie kota malang. Penelitian ini bertujuan untuk mendeskripsikan persepsi siswa terhadap pembelajaran online yang dilakukan selama ini, sehingga diharapkan dapat menjadi jawaban bagi siswa dan memberikan solusi terhadap pelaksanaan pembelajaran online di MA Attaraqqie. Subyek penelitian ini adalah seluruh siswa MA Attaraqqie Kota Malang putra dan putri dalam penelitian ini menggunakan skal likert. Data diperoleh melalui pengisisan pertanyaan-pertanyaan menggunakan skala likert dengan jawaban yang tersedia.Penyebaran angket melalui google form terdapat 101 respoden siswa yang terdata. Berdasarkan paparan hasil penelitian maka bisa disimpulkan bahwa siswa MA Attaraqqie Kota Malang, menginginkan pembelajaran secara tatap muka atau offline. 


\section{PENDAHULUAN}

Berdasarkan surat edaran Mendikbud No 4 Tahun 2020 Tentang Pelaksanaan Kebijakan dan Pendidikan Dalam Masa Darurat Penyebaran Corona Virus Desease (Covid 19). Sejak Bulan Maret 2020 seluruh jenjang Pendidikan di Indonesia baik dari pendidikan dasar sampai Pendidikan tinggi menerapkan belajar dari rumah atau system daring yang biasa kita kenal pembelajaran online. Kebijakan pembelajaran online sampai saat ini masih dilakukan, mengingat belum adanya aturan atau kebijakan dari pemerintah untuk memperbolehkan sekolah dalam menyelenggarakan kegiatan belajar mengajar secara tatap muka atau offline. Beberapa kesempatan, pemerintah mengijinkan untuk mengadakan pembelajaran secara tatap muka, dengan beberapa syarat yang harus ditentukan oleh pihak sekolah. Tarik ulur aturan maupun kebijakan yang diterapkan pemerintah memunculkan berbagai reaksi, baik dari orang tua, guru, maupun peserta didik. Kejenuhan maupun kebosanan yang dirasakan oleh peserta didik, juga dirasakan oleh guru dalam pelaksanaan kegiatan belajar mengajar secara online (Lubis et al., 2021). Keinginan bertemu maupun rindu untuk saling bertatap muka, menjadi penghalang dalam masa pandemi saat ini.

Pembelajaran online merupakan pembelajaran yang dilakukan tanpa tatap muka antara guru dan peserta didik, melainkan pembelajaran melalui media pembelajaran yang telah tersedia. Saat ini pembelajaran online merupakan solusi dalam menjalankan proses pembelajaran, walaupun banyak kendala yang dihadapi oleh peserta didik maupun oleh guru. Sistem pembelajaran online seringkali memunculkan berbagai masalah yang dihadapi oleh guru maupun peserta didik, seperti pendapat (Fitria \& Ifdil, 2020) seringkali siswa mengalami kecemasan untuk belajar secara online, bahkan pemahaman terhadap materi yang disampaikan oleh guru kepada peserta didik, tidak semua peserta didik dapat memahami materi secara langsung. Sejalan dengan pendapat (Meidawati, 2019) setiap siswa belum tentu memiliki sarana pembelajaran secara daring, dimana tidak semua peserta didik mempunyainya, bahkan keterbatasan untuk membeli kuota internet bagi peserta dirik yang kurang mampu juga mempunyai permasalahan tersendiri. Beberapa media pembelajaran secara online pernah diterapkan di MA Attaraqqie kota malang, dari whatshapp group, aplikasi E-Learning, google form, maupun telegram. Berbagai media tersebut merupakan media yang digunakan dalam pembelajaran online oleh guru kepada peserta didik, hal ini menunjukkan bahwa setiap guru maupun peserta harus memahami aplikasi online tersebut. Dalam hal ini, akan menimbulkan persepsi siswa terhadap pembelajaran online yang mampu mengembangkan dan mengontrol dirinya dalam mengolah pengalamannya. 
Penelitian mengenai persepsi sudah banyak diteliti oleh berbagai pihak. Menurut (Komarudin \& Prabowo, 2020) persepsi merupakan kecakapan untuk melihat, memahami, kemudian menafsirkan suatu stimulus sehingga merupakan sesuatu yang berarti dan menghasilkan penafsiran, dimana hasil dari penelitian tersebut menunjukkan bahwa persepsi pembelajaran daring dalam mata pelajaran Pendidikan jasmani, dikategorikan sedang, dengan melihat dan mengamati siswa tidak merasa nayaman dalam pembelajran daring. Sedangkan menurut Harisah dalam (Noviantari \& Payadnya, 2021) pengalaman seseorang maupun latar belakang pengetahuan, latar belakang social, latar belakang fisik sampai latar belakang budaya merupakan faktor-faktor terjadinya persepsi. Sedangkan menurut Walgito dalam (Rachman \& Jamain, 2020) persepsi merupakan suatu proses penginterpretasian dan pengorganisasian terhadap stimulus yang diterima oleh seseorang sehingga menjadi sesuatu yang berarti dan merupakan aktivitas yang berhubungan dalam dirinya. Pendapat lain yang disampaikan oleh Sugiharto dalam (Noviantari \& Payadnya, 2021) menyampaikan bahwa persepsi adalah proses stimulus yang masuk ke dalam alat indera manusia, sehingga manusia dapat mempersepsikan sesuatu yang positif maupun mempersepsikan yang negatif dengan mempengaruhi tindakan manusia secara nyata dan nampak.

Pembelajaran online yang berjalan selama 1 tahun lebih, membuat persepsi ataupun tanggapan dari siswa bermacam-macam, sehingga, pembelajaran online perlu di evaluasi. Evaluasi pembelajaran online dalam (Setemen, 2010) perlu untuk di evaluasi apabila sudah berjalan 1 semester. Persepsi merupakan kecakapan yang dapat dilihat dari tafsiran perilaku atau sikap. Penelitian ini dilakukan untuk mengetahui persepsi siswa MA Attaraqqie. Penelitian ini tidak hanya memfokuskan persepsi siswa dalam satu mata pelajaran, akan tetapi mencakup seluruh mata pelajaran yang selamai ini diikuti oleh siswa. Hal ini dilakukan untuk mengetahui secara keseluruhan persepsi dari siswa. Selama ini guru-guru telah berupaya dalam melaksanakan pembelajaran online secara maksimal, akan tetapi ada beberapa persepsi yang perlu untuk diketahui oleh guru-guru maupun stakeholder MA Attaraqqie dalam melakukan evaluasi dari pembelajaran online selama ini. Oleh karena itu peneliti menganggap perlunya untuk meneliti persepsi siswa Madrasah Aliyah Attaraqqie mengenai pembelajaran selama masa pandemi Covid-19. 


\section{METODE}

Penelitian ini merupakan penelitian deskriptif kuantitatif dengan menggunnakan metode survey (Sugiyono, 2017), melalui teknik pengumpulan data yang dilakukan dengan cara menyebarkan angket melalui media google form, secara online kepada seluruh siswa Madrasah Aliyah Attaraqqie kota malang. Penelitian ini bertujuan untuk mendeskripsikan persepsi siswa terhadap pembelajaran online yang dilakukan selama ini, sehingga diharapkan dapat menjadi jawaban bagi siswa dan memberikan solusi terhadap pelaksanaan pembelajaran online di MA Attaraqqie. Subyek penelitian ini adalah seluruh siswa MA Attaraqqie Kota Malang putra dan putri dalam penelitian ini menggunakan skal likert. Data diperoleh melalui pengisisan pertanyaan-pertanyaan menggunakan skala likert dengan jawaban yang tersedia, yang selanjutnya dibagikan melalui google form. Angket langsung disebarkan kepada seluruh siswa pada bulan juni 2021 dengan berhasil mengumpulkan 101 respon, dari total 150 siswa, akan tetapi 49 siswa tidak mengisi angket tersebut Selanjutnya data dianalisis dari setiap pertanyaan, sehingga dapat dideskripsikan dari jumlah pertanyaan yang paling banyak.

\section{HASIL}

Berdasarkan hasil dari penyebaran angket melalui google form terdapat 101 respoden siswa yang terdata. Pertanyaan pertama jika pembelajaran online diperpanjang bagaimana tanggapan siswa. Dari tanggapan respon siswa bahwa, siswa yang senang diperpanjang sebanyak 22 siswa, sedangkan siswa yang menjawab tidak senang sebanyak 25 siswa, serta siswa yang menjawab biasa saja sebanyak 53 siswa. Siswa yang menjawab senang dikarenakan dapat belajar dari rumah dan dalam mengerjakan tugas mereka tidak kesulitan karena langsung dengan sarana internet. Sedangkan siswa yang menjawab tidak senang memberikan alasan bahwa ingin belajar secara tatap muka atau offline, karena sudah mulai bosan dengan pembelajaran online. Akan tetapi ada siswa yang merespon dengan dilanjutkannya pembelajaran online biasa saja, karena siswa juga menginginkan pembelajaran langsung, dengan bertemu guru langsung. Berbagai alasan yang disampaikan siswa terkait pembelajaran online, walaupun siswa ingin belajar secara langsung, akan tetapi dengan terus meningkatnya kasus penyebaran covid-19, maka perlu saat ini untuk pembelajaran dilakukan secara online. 
Tabel 1. Pertanyaan pertama

\begin{tabular}{|c|c|}
\hline \multicolumn{2}{|c|}{$\begin{array}{l}\text { Apa pendapat anda jika pembelajaran online } \\
\text { jika dilanjutkan }\end{array}$} \\
\hline Senang & 22 \\
\hline Tidak Senang & 25 \\
\hline Biasa Saja & 53 \\
\hline Total Respon & 101 Siswa \\
\hline
\end{tabular}

Gambar 1.

APA PENDAPAT ANDA JIKA

PEMBELAJARAN ONLINE JIKA

DILANJUTKAN

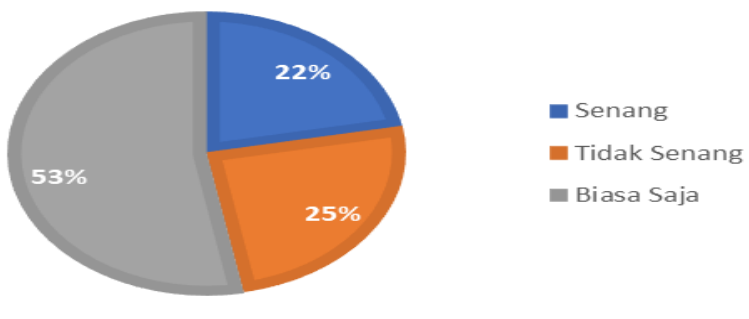

Berdasarkan respon dari siswa pada pertanyaan kedua, apa kendala anda ketika pembelajaran online, didapatkan data sebagai berikut. Siswa yang menjawab sulit memahami materi sebanyak 68 siswa, siswa yang merespon dengan jawaban keterbatasan kuota internet 34 siswa, respon siswa yang menjawab lemah signal 18 siswa, sedangkan yang tidak ada kendala hanya 9 siswa. Alasan yang disampaikan siswa terkait kesulitan yang dihadapi dalam pembelajaran online. Sulit memahami materi merupakan alasan yang paling banyak, dimana siswa kurang maksimal dalam menyimak secara keseluruhan materi yang disampaikan selama pembelajaran online, terkadang ketika pembelajaran berlangsung, siswa hanya mengikuti untuk mengisi absen saja. Lemah signal internet juga menjadi alasan bagi siswa, karena perbedaan tempat tinggal, maupun alat sarana pembeljaran yang dipakai berbeda-beda. Keterbatasan kuota juga menjadi alasan, melihat hampir seluruh siswa mempunyai paket data yang terbatas dalam setiap bulannya, hal ini juga dengan adanya keterbatasan ekonomi yang dialami berbagai siswa. sedangkan ada sekitar 9 siswa yang tidak mengalami kendala dalam pembelajaran online, karena fasilitas yang mereka pakai sudah lengkap. 
Tabel 2. Pertanyaan kedua

\begin{tabular}{ll}
\hline \multicolumn{2}{c}{ Apa kendala anda ketika pembelajaran online } \\
\hline Kuota internet & 34 \\
\hline $\begin{array}{l}\text { Sulit memahami } \\
\text { materi }\end{array}$ & 68 \\
\hline Lemah signal & 53 \\
\hline Tidak ada kendala & 9 \\
\hline Total Respon & 101 \\
& Siswa \\
\hline
\end{tabular}

Gambar 2.

APA KENDALA ANDA KETIKA

PEMBELAJARAN DARING

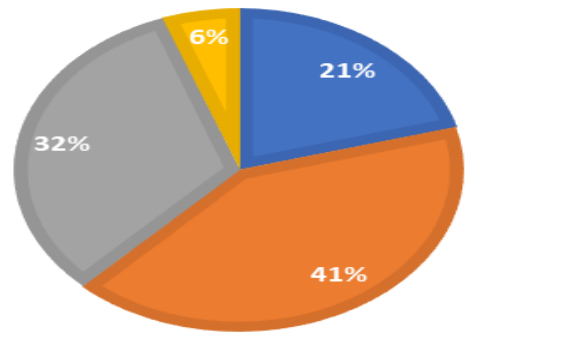

- Kuota internet

- Sulit memahami materi

- Lemah signal

- Tidak ada kendala

Berdasarkan respon dari siswa pada pertanyaan ketiga, apa saran yang digunakan dalam pembelajaran online, didapatkan data sebagai berikut. Hampir seluruh siswa yang menjawab menggunakan $\mathrm{Hp}$, yaitu sebanyak 84 siswa. menggunakan HP dan laptop sebanyak 17 siswa. Sedangkan siswa yang menggunakan Laptop tidak ada. Tidak ada siswa yang menggunakan laptop saja, karena siswa lebih memanfaatkan HP daripada laptop, akan tetapi ada siswa yang terkadang menggunakan Hp maupun laptop secara bersamaan dalam pembelajaran tersebut.

Tabel 3. Pertanyaan ketiga

Apa sarana belajar yang digunakan saat pembelajaran online?

\begin{tabular}{ll}
\hline Hp & 84 \\
\hline Laptop & 0 \\
\hline Laptop dan Hp & 17 \\
\hline Total Respon & 101 \\
& Siswa \\
\hline
\end{tabular}




\section{Gambar 3.}
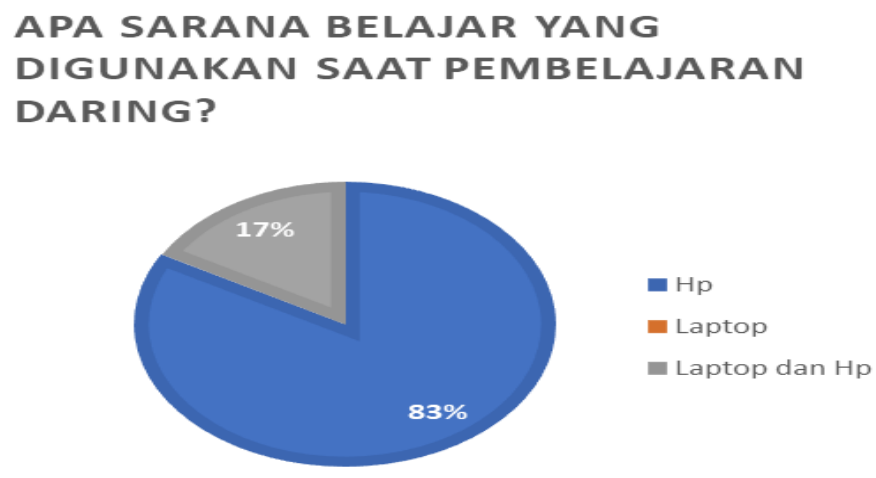

Berdasarkan respon dari siswa pada pertanyaan keempat, apa media yang membuat anda senang dalam pembelajaran daring atau online, didapatkan data sebagai berikut. Siswa yang merespon lebih senang menggunakan Whatshap sebanyak 73 siswa, sebanyak 31 siswa senang menggunakan aplikasi E learning, sedangkan yang senang menggunakan telegram sebanyak 16 siswa, siswa yang senang menggunakan aplikasi telegram sebanyak 16 siswa., sedangkan sebanyak 7 siswa senang menggunakn aplikasi Zoom atau Google meet. Hampir seluruh siswa senang menggunakan aplikasi whatshap, karena lebih mudah dan tidak banyak menggunakan kuota.

Tabel 4. Pertanyaan keempat

\begin{tabular}{ll}
\hline \multicolumn{2}{c}{$\begin{array}{c}\text { Apa media yang membuat anda senang dalam } \\
\text { pembelajaran online }\end{array}$} \\
\hline Whatshap & 73 \\
\hline Telegram & 16 \\
\hline E Learning & 31 \\
\hline Zoom/Google Meet & 7 \\
\hline Total Respon & 101 \\
& Siswa \\
\hline
\end{tabular}

Gambar 4.
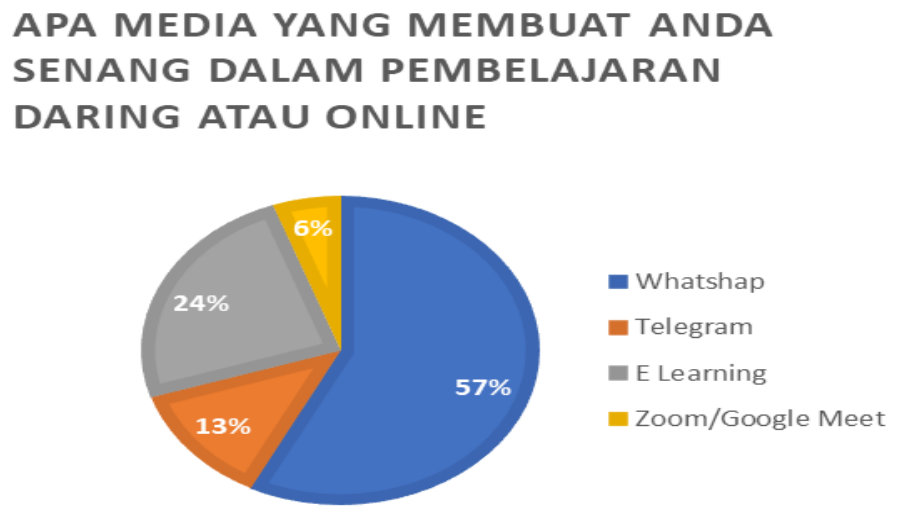
Berdasarkan respon dari siswa pada pertanyaan kelima, apa media yang membuat anda senang dalam pembelajaran online, didapatkan data sebagai berikut. Siswa yang merespon sangat memahami hanya 2 siswa, siswa yang memahami hanya 30 siswa, sedangkan 6 siswa tidak memahami materi yang disampaikan dalam pembelajaran, bahkan 70 siswa yang kurang memahami materi yang disampaikan dalam pembelajaran. berdasarkan data tersebut, banyak siswa yang kurang memahami pembelajaran secara online, dengan berbagai alasan yang disampaikan siswa maupun guru, terkadang siswa yang tidak mengerjakan tugas, bahkan siswa tidak bersungguh-sungguh dalam mengikuti pembelajaran online selama ini.

Tabel 5. Pertanyaan kelima

\begin{tabular}{ll}
\hline \multicolumn{2}{c}{$\begin{array}{c}\text { Apakah anda memahami materi yang } \\
\text { disampaikan selama pembelajaran online? }\end{array}$} \\
\hline Sangat Memahami & $\mathbf{2}$ \\
\hline Memahami & $\mathbf{3 0}$ \\
\hline Tidak memahami & $\mathbf{6}$ \\
\hline Kurang memahami & $\mathbf{7 0}$ \\
\hline Total Respon & $\mathbf{1 0 1}$ \\
& Siswa \\
\hline
\end{tabular}

\section{APAKAH ANDA MEMAHAMI MATERI \\ YANG DISAMPAIKAN SELAMA \\ PEMBELAJARAN DARING ATAU ONLINE?}

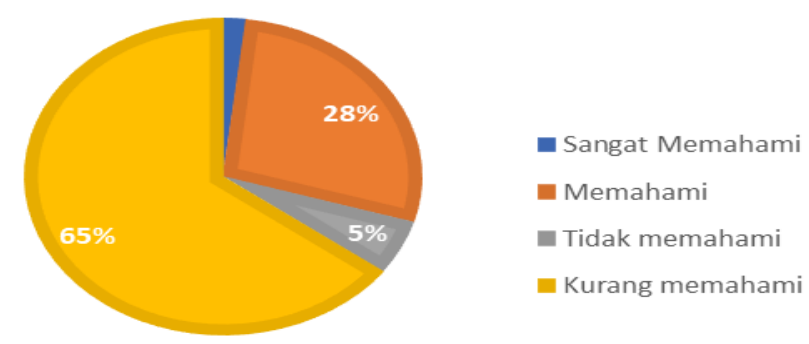

\section{SIMPULAN}

Berdasarkan paparan hasil penelitian maka bisa disimpulkan bahwa siswa MA Attaraqqie Kota Malang, menginginkan pembelajaran secara tatap muka atau offline, kendala dalam pembelajaran daring atau online banyak siswa yang sulit untuk memahami materi yang disampaikan, walaupun sarana pembelajaran siswa banyak menggunakan $\mathrm{Hp}$, dimana alat elektronik yang saat ini selalu dibawa oleh siswa, ternyata keinginan siswa untuk belajar secara mandiri masih kurang. Media yang digunakan saat pembelajaran online juga 
mempengaruhi kesenangan siswa dalam pembelajaran. Masih ada siswa yang tidak mengikuti pembelajaran online secara serius, sehingga mereka banyak yang kurang memahami materi dari guru.

\section{DAFTAR RUJUKAN}

Fitria, L., \& Ifdil, I. (2020). Kecemasan remaja pada masa pandemi Covid -19. Jurnal EDUCATIO: $\quad J$ Jurnal Pendidikan Indonesia, $\quad 6(1), \quad 1$. https://doi.org/10.29210/120202592

Komarudin, \& Prabowo, M. (2020). Persepsi Siswa Terhadap Pembelajaran Daring Mata Pelajaran Pendidikan Jasmani Olahraga Dan Kesehatan Pada Masa Pandemi Covid19. Majalah Ilmiah Olahraga (MAJORA), 26(2), 56-66.

Lubis, H., Ramadhani, A., \& Rasyid, M. (2021). Stres Akademik Mahasiswa dalam Melaksanakan Kuliah Daring Selama Masa Pandemi Covid 19. Psikostudia: Jurnal Psikologi, 10(1), 31. https://doi.org/10.30872/psikostudia.v10i1.5454

Meidawati, S. A. N. B. R. (2019). Persepsi Siswa Dalam Studi Pengaruh Daring Learning Terhadap Minat Belajar Ipa. SCAFFOLDING: Jurnal Pendidikan Islam Dan Multikulturalisme, 1(2), 30-38. https://doi.org/10.37680/scaffolding.v1i2.117

Noviantari, S., \& Payadnya, A. A. (2021). Jurnal Pembelajaran dan Pengembangan Matematika, Vol. 1, No. 1 (Maret 2021) Program Studi Pendidikan Matematika, Fakultas Keguruan dan Ilmu Pendidikan, Universitas Mahasaraswati Denpasar ISSN: 1(1), 13-22.

Rachman, A., \& Jamain, R. R. (2020). Persepsi Mahasiswa Bimbingan dan Konseling Terhadap Pembelajaran Online pada Masa Pandemi Covid-19. Prosiding Seminar Nasional Bimbingan Dan Konseling Universitas Negeri Malang "Arah Kurikulum Program Studi Bimbingan Dan Konseling Indonesia Di Era Merdeka Belajar, 43-49.

Setemen, K. (2010). Pengembangan Evaluasi Pembelajaran Online. Jurnal Pendidikan Dan Pengajaran, 43(3), 207-214.

Sugiyono. (2017). Metode Penelitian Kuantitatif, Kualitatif dan $R \&$ D. Alfabet. 